\title{
The Instructional Influence on the Acquisition of Spanish Subjunctive
}

\author{
Diana Hsien-jen Chin \\ Department of Spanish, Wenzao Ursuline University of Languages, Taiwan
}

Copyright $\bigcirc 2016$ by authors, all rights reserved. Authors agree that this article remains permanently open access under the terms of the Creative Commons Attribution License 4.0 International License

\begin{abstract}
The present study investigates whether form-focused instruction enhances Chinese (L1)-English (L2)-Spanish (L3) learners' ability of interpreting the semantic entailment marked by the subjunctive and the indicative moods in Spanish predictive conditional clauses. Three groups participated in the study: (1) the native group (2) the tutored group (3) the untutored group. The tutored group received four-hour form-focused instruction on mood selection in predictive conditional clauses. The results reveal that form-focused instruction facilitates learners' interpretation of the subjunctive mood in conditional clauses. It is most effective in differentiating the irrealis conditions marked by the imperfect subjunctive. The instruction successfully directs Spanish learners' attention to mood morphology and the contextual queues that require the presence of subjunctive. In addition, the instructional effects are retainable.
\end{abstract}

Keywords Form-focused Instruction, Spanish Subjunctive, Chinese-English-Spanish Learners, L3 Acquisition, Mood

\section{Introduction}

The subjunctive mood in Spanish has been considered one of the most difficult features to acquire by many scholars. Although previous studies have revealed that explicit instruction on subjunctive facilitates acquisition, these studies have focused mainly on Anglophone L2 learners (e.g. Collentine[1-4]; Farley[5-7]; Gudmestad[8]; Fernández[9]). How non-Anglophone learners acquire the subjunctive mood in Spanish has not been thoroughly explored.

For Chinese-speaking Spanish learners, the hurdle in acquiring the subjunctive mood is attributed to its absence in their native language. The task of acquiring the Spanish subjunctive requires knowledge of morphology, semantics, and awareness of the contextual queues. The conditional clauses are one of the most problematic structures, because their interpretation relies on the matrix of mood and tense, as illustrated in (1)-(3).
(1) Si hace calor,
if do-3rd sing.-present-indicative heat,
nos quedaremos $\quad$ en casa.
pron.- $1^{\text {st }}$ pl. stay- $1^{\text {st }}$ pl.-future-indicative in house

If it is hot, we will stay at home.

(2) Si hiciera calor, if do-3rd sing.-past-imperfect-subjunctive heat, nos quedaríamos en casa. pron. $-1^{\text {st }}$ pl. stay $-1^{\text {st }}$ pl.-conditional-indicative in house If it were hot, we would stay at home.

(3) Si hubiera hecho calor, if do- $3^{\text {rd }}$ sing.-past-pluperfect-subjunctive heat, nos habríamos quedado pron. $-1^{\text {st }}$ pl. $\quad$ stay- $1^{\text {st }}$ pl.-conditional-perfect-indicative en casa.

In house

If it had been hot, we would have stayed at home.

To obtain an accurate interpretation, learners have to be familiar with the subjunctive mood, the context, and the interpretation entailed by the mood and tense morphology. In Chinese, mood and tense are not explicitly expressed by morphology. They are context driven. In addition, the subjunctive mood is not present in Chinese. The Spanish conditional clauses illustrated in (1)-(3) share the same translation in Chinese, as shown in (4). Based on Stockwell, Bowen, and Martin's[10] hierarchy of difficulty, the most difficult category to learn is to differentiate a linguistic feature that is presented in one form in the L1 but has two or more presentations in the target language, like the subjunctive and indicative marking in Spanish predictive conditional clauses. There is only one way of expressing predicative conditions in Chinese, regardless of its possibility level; whereas in Spanish, different mood and tense morphology marks conditions with different credibility. Therefore, acquiring the correct interpretation for the Spanish conditional clauses is a difficult task for Chinese-speaking learners. 
(4) ruguo techi re, women jun dai zai jia. if weather hot, we then stay at home

If it is hot, we will stay at home.

Even though the syntactic structure of conditional clauses is introduced in Spanish classes, there is no explicit explanation on the interpretation conveyed by the subjunctive morphology. Collentine[11] suggests that learners' awareness of the Spanish subjunctive is essential to enhance their knowledge of mood selection. Therefore, explicit instruction on the target structure and mood selection is indispensable.

In the following sections, I will first summarize the findings of previous research on the acquisition of Spanish subjunctive. Then, the structure of the predictive conditional clauses in Chinese, English, and Spanish will be presented. After that, I will present the study. Later, I will discuss the findings and how they relate to the previous research. Finally, I will conclude this paper with suggestions for pedagogical implications and future research.

\section{Background}

\subsection{The Acquisition of Subjunctive in L2 Spanish}

Many factors affect a successful acquisition of the Spanish subjunctive mood. From the perspective of Universal Grammar (UG), learners' syntactic knowledge is fundamental for the acquisition of mood selection. Ellis [12] states that syntax is the core of UG, while morphological knowledge is the periphery. In other words, syntactic environment sets up the condition for acquiring morphology. Bardovi-Harlig and Bofman[13] examined the development of Spanish L2 learners' linguistic development. They found that learners' syntactic knowledge is developed before the acquisition of morphology. Moreover, syntactic similarities between the L1 and the L2 promote the acquisition of morphology.

In the case of acquiring the Spanish subjunctive, Collentine [1] found that English-speaking learners' errors in applying the correct subjunctive mood in nominal clauses was due to the insufficient knowledge of the syntactic structure. He further reported that the learners used infinitive verbs in contexts where subjunctive is required. Since the subjunctive morphology is not present in modern English, Collentine[1] attributed these errors to L1 transfer. Similar findings were also reported in Bruhn de Garavito's[14] study comparing multilingual and monolingual Spanish learners acquiring coreference in adjectival clauses. Learners scored lower with the subjunctive sentences requiring obligatory coreference than non-coreferential sentences. The coreferentiality in adjectival clauses is not subjected to mood selection in English; hence, Bruhn de Garavito[14] claimed that such results are due to L1 transfer. Both Collentine's[1] and Bruhn de Garavito's[14] studies reveal that their participants are at the pre-syntactic stage (Givón[15, 16]). To apply the accurate mood, learners need to have mastered the verbal inflection and they have to reach the syntactic stage. However, when do L2 Spanish learners reach the syntactic stage?

Collentine[4] examined the correlation between advanced Spanish learners' syntactical and morphological behaviors by assessing their ability of decoding syntax and morphology in discourse. Although the advanced learners demonstrated some native-like behaviors, their performance in decoding the syntactic and morphological features in discourse was different from native speakers. Collentine's[4] findings suggest that reaching syntactic stage requires advanced proficiency in the target language. However, a native-like syntactic behavior seems to be hard to accomplish.

Borgonovo and Prévost[17] investigated whether very advanced Francophone Spanish learners can attain native-like judgement on sentences with polarity subjunctive. The learners exhibited native-like behavior in the judgment tasks. Like the natives, L2 learners accepted polarity subjunctive in both presupposed and non-presupposed contexts. Besides, both groups judged the use of subjunctive more acceptable in presupposed than in non-presupposed contexts. This indicates that learners with very advanced proficiency in Spanish are able to overcome the transfer effects and successfully acquire the subjunctive mood. Borgonovo and Prévost's[17] findings reveal that parameter resetting is possible and UG is still accessible to adult learners in the domain of subjunctive.

Even though these studies reveal that subjunctive can be successfully acquired when learners' linguistic proficiency reaches very advanced level, the ultimate attainment is not obtainable to all L2 learners. Collentine[3], Gudmestad[8], and Velasco-Zárate[18] explored the hurdles that learners have to conquer in the process of acquiring Spanish subjunctive. Collentine[3] proposed the internal and external factors affecting L2 subjunctive development. The internal factors include cognition, exposure to the target language, and syntactic deficiency.

Cognition is related to the distinction between learning and acquiring proposed in Krashen's[19] Monitor Model. Terrell, Baycrof, and Perrone[20] state that the fact that learners' accurate usage of subjunctive is more frequently found in monitored tasks than vernacular tasks suggests that their knowledge of subjunctive is learned, not acquired. Another factor that influences the acquisition of subjunctive is exposure. Residence or study abroad in Spanish-speaking countries improves learners' ability of using subjunctive (Stokes[21]; Stokes and Krashen[22]).

Furthermore, crosslinguistic influence from the $\mathrm{L} 1$ is also a prominent factor in acquiring subjunctive. Velasco-Zárate[18] investigated Anglophone and Japanese-speaking learners acquiring the Spanish subjunctive in adjectival clauses. The Anglophone participants' correct interpretation of the specificity marked by subjunctive was due to the presence of determiner phrase and article in their L1. By contrast, the absence of these features in Japanese posed difficulty in assigning correct interpretation to sentences marked with definite articles for the Japanese L1 learners. Hence, Velasco-Zárate[18] concluded that the syntactical and 
morphological differences between Japanese and Spanish in expressing the subjunctive mood causes difficulties to the acquisition.

On the other hand, external factors such as input and instruction also affect the outcome of acquisition. The input factor concerns with how learners are exposed to the sentences that contain subjunctive and how their attention is attracted to the target structures. Lee[23] suggests that subjunctive is often ignored by learners due to its low communicative value. In his study testing whether early exposure to subjunctive enhances learners' reading comprehension, Lee[23] found that exposure to subjunctive does not improve learners' comprehension of the text. Lee and Rodríguez[24] state that morphological saliency attracts learners' attention to the subjunctive mood. Moreover, Gudmestad[8] claims that as learners' proficiency improves, the influence of saliency diminishes. Linguistic saliency attracts learners' attention to the input, which is essential for successful acquisition of the subjunctive.

Therefore, Robinson[25, 26] suggests that knowledge of complex rules are more likely to be acquired under enhanced learning conditions in which some heuristic modification is carried out in the attempts to draw the learners' attention to a targeted grammatical phenomenon. In other words, raising learners' metalinguistic awareness on the structures where the subjunctive mood is required should be the center of pedagogical practice.

\subsection{Effects Form-focused Instruction on Acquiring the Spanish Subjunctive}

Following the notion of metalinguistic awareness, many researchers have explored different pedagogical approaches in teaching the Spanish subjunctive. Terrell, Baycroft, and Perrone[20] claim that guided instruction attracts students' attention to the target structure and it shortens the process of acquisition. Regarding the effects of form-focused instruction on the acquisition of the Spanish subjunctive, previous research comparing form-focused instruction with other pedagogical methods did not reveal a robust result.

Collentine[11] examined the effectiveness of input-oriented and output-oriented instruction in learning the subjunctive mood selection in adjectival clauses. The input-oriented instruction focused on the syntactic structures that require the subjunctive mood. On the other hand, the output-oriented instruction aimed to provide feedback on learners' usage of the subjunctive. The results revealed intermediate level Spanish L2 learners in both input-oriented and output-oriented groups had significantly higher accuracy than the control group in the interpretation and the production tests. However, no significant differences were found between the instructed groups. Learners' accuracy in the interpretation and production tests significantly improved in both groups. Even though the two instructional approaches are at two extremes of the learning process, their influence on the acquisition of the subjunctive mood is homogeneous. That is, explicit instruction is facilitative, but which instructional method is more effective remains unclear.

Collentine et. al.[27] further investigated whether form-focused instruction on the syntactic structures of the adjectival clauses enhances the learners' ability of extracting the coreference in adjectival clauses. The participants were intermediate level Anglophone Spanish L2 learners. They were assigned to one of the three groups: (1) control (2) syntax-subjunctive instruction (3) subjunctive instruction only. The participants' responses in a recognition and a production tasks were analyzed. Both groups' accuracy improved significantly in the posttest, even though the participants' responses in the syntax-subjunctive group showed a positive instructional effect, they did not outperform those in the subjunctive-only group.

As for the production task, both instructed groups showed increase in the accurate usage of subjunctive in the posttest, whereas the control group used the same amount of subjunctive in both pretest and posttest. Although there was no significant difference between the instructed groups, the syntax-subjunctive group committed less errors in the contexts where indicative is required. In addition, less cases of overgeneralization were found in this group.

These findings indicate that form-focused instruction on the syntactic structure is facilitative for acquiring the Spanish subjunctive, which confirms that syntactic knowledge prepares learners for mood acquisition. Moreover, Collentine[11] [27] state that the learners' pre-existing knowledge of the Spanish subjunctive might have contributed to the insignificant difference found between the instructed groups. Exposure to the subordinate clauses marked by subjunctive in previous instruction and textbooks might have interfered the instructional effects. Hence, he concluded that learners' knowledge of the syntactic structure where the subjunctive mood is required establishes the foundation for effective acquisition. This suggests that form-focused instruction integrating an explanation on the syntactic structure of subordinate clauses is advantageous for learning the subjunctive mood. It provides learners with a better understanding of the syntactic distribution of the subjunctive.

Nevertheless, García's[28] study examining German-speaking Spanish L2 learners learning the subjunctive mood revealed contradictory results. The three groups in García's[28] study received input-oriented, output-oriented, and no instruction (i.e. control group) respectively on the subjunctive mood in three clauses: relative, temporal, and concessive. The input-oriented group received form-focused instruction that directed the learners' attention to the structures where the subjunctive mood is required. The output-oriented instruction focused on the learners' correct usage of the subjunctive within the context without providing explicit explanation on the structure. Even though the two instructional groups received instructions with different focuses (i.e. interpretation vs. production), no significant differences were found in the interpretation and production tasks regarding the methods investigated. This reveals that form-focused instruction is not particularly effective in facilitating the 
acquisition of the Spanish subjunctive. On the other hand, the control group also showed a significant difference in the posttests even without any instruction. Nevertheless, the improvement did not last through the second posttest. García[28] claimed the control group's improvement was due to the participants' familiarity with the test format.

In sum, previous studies indicate that explicit instruction facilitates the acquisition of the Spanish subjunctive. Nevertheless, whether form-focused instruction benefits the acquisition. The possible factors that contribute to such findings are the participants' Spanish proficiency level, the length of retention, and the instruments.

The participants in these studies were intermediate level learners. It is possible that their Spanish proficiency had not reached the level that prepares them to acquire the syntactic structures where subjunctive is required. Although the lack of previous knowledge of the subjunctive mood makes them ideal participants for the research on instructional effects, their low proficiency also poses a problem to interpreting the findings. The acquisition of the subjunctive mood requires advanced proficiency and syntactic knowledge. Moreover, as stated by Collentine[2] and Gudnestad[8], even advanced learners are unable to obtain the correct interpretation entailed by the subjunctive mood like natives. Hence, it is possible that the participants in previous studies were not linguistically ready for the instruction.

Another factor that might contribute to such results is the short time elapse between the instruction and the posttests. In the studies of Collentine[11] and Collentine et. al.[27], the posttest was administered one or two days after the instruction. In García's[28] study, two posttests were implemented, one immediately after the instruction, the other a week post the instruction. With limited time between the posttests or with only one immediate posttest employed, what the researchers found effective was the short-term pedagogical effects.

The previous studies on the instructional effects on the acquisition of subjunctive compare the pedagogical methods manipulating the learning process (e.g. processing input, instructed input, focus on form) with learners who do not receive specific instruction. As interpretation/ judgement test being one of the most implemented instrument, what learners were tested in these studies was not what they were taught. That is, even though the instructions focused on initiating the process of the subjunctive mood, the test results did not reflect that. This might have contributed to the fact that no significant results were found between the different methods on teaching the Spanish subjunctive.

\subsection{Spanish Language Instruction in Taiwan}

Different from the European and Anglophone learning environment, Spanish is a less frequently taught/learned language in Taiwan. Students do not have any exposure to Spanish prior to college. When they start to learn Spanish in college, they are true beginners. College freshmen decide their majors before they start the first semester. Most students taking the courses are Spanish majors. They spend four years learning Spanish, and have to pass the DELE (Diploma de Español como Langua Extranjera) exam at B1 level under the CEFR framework before graduation.

Students receive an average of 14 hours of instruction on Spanish language per week. The courses include grammar, oral practice, listening comprehension, reading, and other content courses such as literature, history, and linguistics. The language of instruction for the first two years is mainly Chinese (i.e. the students' L1), except for oral practice. The usage of Spanish as the instructional language increases as the learners' proficiency improves. The grammar and oral practice courses for the first three years are conducted under a thematic approach through collaboration among the instructors. They use the same textbook with each unit presenting a topic (e.g. shopping, asking directions, talking about history...etc.). The students learn the structures and linguistic features needed for each topic in the grammar class, and put them into practice in the oral practice class. For the seniors, the grammar and the oral practice courses are optional. Instead, they can take other content courses taught in Spanish, such as Hispanic history, literature, and culture.

Considering the curriculum design and the learning context, a grammar course conducted with the form-focused approach serves the students' need and their learning goal. A form-focused grammar course is not Focus on FormS. Unlike the Focus on FormS approach, which presents the grammatical rules in isolation; the structures and grammatical rules are presented within context, usually a reading text, and under a practical theme in a form-focused class. Furthermore, in a Focus on FormS class, the activities are mainly structure-driven, aiming to reinforce students' declarative knowledge on the target forms. The students' communicative needs are not the priority of the instruction. On the other hand, form-focused activities aim to draw learners' attention to the structures and linguistic features needed for the oral practice activities, and to provide explicit explanations on the usage and rules of the target features. The ultimate goal is to satisfy the students' communication need and to prepare them with the required linguistic knowledge to perform the tasks in the oral practice class. The rules are presented and explained with contextualized examples and exercises, such as verb morphology exercises, sentence judgment, matching sentences with context, and free writing. The controlled exercises strengthen the learners' declarative knowledge of the target structures. The judgment and sentence pairing exercises provide learners with opportunities to reflect on their knowledge. Free production like free writing exercise stimulates communicative usage of the rules and structures learned and promotes automatization of the learners' linguistic knowledge.

On the other hand, form-focused grammar instruction is not Focus on Form (Long and Robinson[29]; Doughty and Williams[30]) either. Differing from the reactive grammar instruction in a Focus on Form classroom, explicit grammatical explanation in a form-focused grammar class is 
proactive. It is provided before learners encounter the communication need. In a Focus on Form class, explicit explanation on grammar rules and structures is initiated by learners' errors and the difficulties that they encountered in the process of communication. By contrast, in a form-focused class, the instructor determines what rules and structures are essential to fulfill the students' communication needs. Moreover, a Focus on Form syllabus is content-based and task driven (e.g. doing a research on a historic event, writing business letters...etc.), whereas the syllabus for a form-focused course is thematic (e.g. environmental issues, childhood memories...etc.) and the content is language centered.

The Focus on FormS approach has been criticized as being form-driven and communicatively isolated. It does not correspond to learners' needs and the ultimate goal of current SLA pedagogy. Nevertheless, Sheen[31] claims that grammar teaching should form the framework for language pedagogy. A language class without explanation of grammatical rules would make students feel disoriented. On the other hand, the Focus on Form approach has its shortcoming as well. In order to perform content-based tasks, learners need to achieve certain level of language proficiency. For instance, it is difficult for beginners to conduct a research on Mayan civilization or write a business letter in Spanish. This approach is more suitable for advanced learners.

However, even advanced learners prefer to receive Focus on FormS instruction on specific grammatical rules. In a survey conducted by Burgess and Etherington[32] with 48 instructors teaching English for Academic Purpose classes, they reported that more than $70 \%$ of the instructors considered explicit grammar instruction and frequent practice on the target rules and structures contribute to accuracy and fluency. They found that advanced learners did not feel frustrated when involved in problem-solving tasks, but they did feel frustrated when encountered linguistic difficulties and grammatical errors. Furthermore, Sheen[31] claims that Focus on Form only corrects the errors that impede communication. The lack of correction on errors that do not cause communication difficulty might contribute to fossilization or overgeneralization. This suggests that even for learners with advanced proficiency, the fact that explicit grammar instruction is preferred does not coincide with the Focus on Form principles.

Since both Focus on Form and Focus on FormS have their shortcomings, a form-focused instruction takes the middle position by providing preemptive explicit grammatical instruction to language learners. It is appropriate for less proficient learners, because its thematic syllabus is constructed with communicative goals. Learners are not required to perform a task that they are unable to do in a foreign language, and this enables them to concentrate on learning the target language. Besides, it is suitable for a collaborative curriculum, like the one implemented in the Taiwanese learning context. The form-focused instruction prepares students for the upcoming communicative activities and put them in ease when communicating in a less exposed foreign language.

\subsection{The Predictive Conditional Clauses in Spanish, English, and Chinese}

The structure investigated in the present study is the predictive conditional clauses. Palmer[33] defines a predictive conditional clause as a subordinate clause that holds a cause-effect relationship with the principal clause. The conditional clause depicts a situation in which the principal clause is true. In other words, the validity of a conditional clause and its principal clause is interdependent. The predictive conditional clause in Spanish requires the indicative mood when it depicts a possible situation, as presented in (5). Henk[34] states that the indicative mood in the subordinate clause is required due to the high information value of the conditional clause. That is, the truth value of the principal clause is related to the validity of the conditional clause. In this sense, the indicative mood is necessary to present the validity of the occurrence of the condition depicted in the subordinate clause. In (5), whether the principal clause "lo compraré" is true depends on the truth value of the conditional clause " $\mathrm{Si}$ tengo dinero." The indicative mood on "tengo" implies that the occurrence of such condition is possible. Henk[34] categorizes this type of conditional clauses as potentialis conditionals, where the hypothetical connection between the protasis and the apodosis is valid if the event presented in the conditional clause can be carried out in reality.
(5) Si tengo dinero, lo
if have- ${ }^{\text {st }}$ sing.-indicative-present money it compraré.
buy- $1^{\text {st }}$ sing.-indicative-future

If I have money, I will buy it.

A possible predictive condition in present is marked by the present tense in English, like the example (6). Whether the principal clause "I will buy it" is realized depends on the occurrence of the conditional clause "If I have money." In other words, the truth value of the principal clause can only be verified when the conditional clause is proofed to be an actual fact. In English, a modal verb (e.g. may, might, shall, should, will, would) is required in the principal clause if the subordinate clause depicts a predictive condition.

\section{(6) If I have money, I will buy it.}

The unreal conditional clauses present conditions that are not realizable in actual situation. The unreality is marked by the imperfect subjunctive. The subjunctive mood in Spanish presents a redundant reflection of modality expressed in the principal clause. The conjunction "si" is not compatible with the present subjunctive. Solano-Araya[35] claims that this is due to the undetermined truth value of the conditional conjunction "si". The subjunctive mood normally presents uncertainty in adverbial subordinate clauses. Since the conjunction already expresses a hypothetical situation, marking the subordinate verb with the present subjunctive 
would lead to information redundancy. Moreover, for realis condition, the subordinate and the principal clauses posse parallel structures. Both clauses are presented with the indicative mood. By contrast, the subordinate and the principal clauses of irrealis condition do not have parallel structures. The principal verb is marked with the conditional, and the subordinate verb appears in the imperfect subjunctive. The unparalleled structure presents a situation that does not correspond with the reality at present.

An example of irrealis condition is presented in (7). The combination of the imperfect subjunctive "tuviera" in the subordinate clause and the conditional "compraría" in the principal clause indicates a counterfactual condition. Comparing the examples in (5) and (7), the principal clause in (5) depicts a situation that is possible to be realized, but it has not yet occurred. In (7), the situation is also unrealized, but its occurrence is not possible.

\section{(7) Si tuviera dinero, lo \\ if have- $1^{\text {st }}$ sing.-subjunctive-past money it compraría. \\ buy- $1^{\text {st }}$ sing.-indicative-conditional \\ If I had money, I would buy it.}

The unreal condition is marked by past tense in English. As shown in (8), the principal clause in English requires a modal verb marked with past tense morphology (i.e. would). The subordinate verb is marked in past tense (i.e. had) as well, which implies that such condition is unrealizable in the present. Since the truth value of the principal clause "I would buy it" depends on whether "if I had money" is true, it is impossible for the activity depicted in the principal clause to be carried out.

(8) If I had money, I would buy it.

The unparalleled structure is also present in conditional clauses that express irrealis in past. Since the imperfect subjunctive expresses an unreal condition in the present, the pluperfect subjunctive is employed to indicate a condition that does not agree with what actually happened. On the other hand, the conditional perfect is required in the principal clause. This is illustrated in (9). The verb "hubiera tenido" is marked with pluperfect subjunctive to deliver unreality. The pluperfect locates such situation in a remote past. The conditional perfect "habria comprado" indicates that the occurrence of the situation was not carried out. The difference between examples (7) and (9) is the tense. The combination of the subjunctive in the subordinate clause and the conditional in the principal clause denotes the impossible occurrence of a situation. The imperfect subjunctive is required when such situation is related to the present. Since the pluperfect presents an activity that happened prior to the past, the pluperfect subjunctive is employed to mark a counterfactual condition.

(9) Si hubiera tenido dinero, lo

if have-1st sing.-subjunctive-pluperfect money it

habría comprado.

buy-1st sing.-indicative-conditional perfect

\section{If I had had the money, I would have bought it.}

The unreal conditions in the past are conveyed by pluperfect in English, with the principal clause marked by present perfect with past tense modal verbs, as exemplified in (10). The pluperfect in the conditional clause (i.e. had had) indicates an unreal condition in the past. The combination of the past tense modal verb "would" and the present perfect verb "have bought" expresses a situation unrealized in the past. In other words, the true situation is that I did not have money, so I did not buy it.

(10) If I had had money, I would have bought it.

As illustrated in (5)-(10), the subjunctive mood is not present in English; therefore, the past tense is used to deliver counterfactual condition in the present and the pluperfect for an unreal condition in the past. Regarding the verb morphology in the principal clauses, a modal verb is required, and its tense is marked accordingly to maintain the temporal coordination between the principal and the subordinate clauses. On the other hand, the subjunctive mood is employed to express unreal condition in Spanish subordinate clauses. In addition, the past tense marks counterfactual conditions as well. The principal verb is marked with future tense (i.e. future or conditional) to indicate that such situation has not occurred. In sum, the unreal condition is only marked by tense in English, but it is marked by both mood and tense morphology in Spanish. Moreover, the modal verbs are required in the principal clause in English, but such verbs are not present in Spanish.

Unlike Spanish and English, Chinese does not make distinction between real and unreal condition by mood and verb morphology. A condition is true or not depends on the context. This is exemplified in (11), (12), and (13). There is no distinction on verb "you" (have) in the conditional clause in (11) and (12), even though they express conditions with different level of possibility. The temporal adverbs "shiantzai" (right now) in (12) and "chiunian" (last year) in (13) denote the time of the clauses. The subordinate connector "ruguo" (if) conveys a hypothetical condition. The validity of such condition is determined by the context conveyed by adverbs such as those demonstrated in the examples (12) and (13). If the conditional clauses are uttered within a mutually comprehended context, the temporal adverbs are not necessary. In that case, all conditional clauses would be the same, regardless its validity. The principal clauses in (11)-(13) are the same. The possibility of realizing the situation depicted in the principal clause depends on the truth value of the conditional clause.

(11) ruguo wo you chian, (wo) jiouhuei mai ta. if I have money (I) will buy it If I have money, I will buy it.

(12) ruguo wo shiantzai you chian, (wo) jiouhuei mai ta. if I right now have money (I) will buy it If I had money right now, I would buy it.

(13) ruguo wo chiunian you chian, (wo) jiouhuei mai ta. if I last year have money (I) will buy it 
If I had had money last year, I would have bought it.

In sum, the predictive conditional clauses in Spanish are marked with mood and tense to distinguish realis from irrealis. The distinction between indicative and subjunctive mood is not present in English; therefore, it employs present tense to mark realizable conditions and past tense to mark counterfactual conditions. Finally, as Chinese does not have mood and tense morphology, context is an essential element to determine the validity of conditions.

For the Chinese-English bilinguals learning Spanish as the L3, acquiring the distinction marked by mood and tense morphology in the Spanish predictive conditional clauses is quite challenging. First of all, they are learning a linguistic feature that is not present in neither the L1 nor the L2. Second, they are required to be familiar with the mood and tense morphology in order to detect the correct interpretation conveyed in the conditional clause. Finally, they have to be familiar with the fact that there might not be contextual cues to facilitate the interpretation of conditional clauses in Spanish. Therefore, acquiring the predictive conditional clauses in L3 Spanish is a triple task that requires the knowledge of morphology, syntax, and semantics. However, the acquisition of the Spanish conditional clauses has been neglected by scholars, especially with the Chinese-speaking learners, which inspires the present study.

\section{The Present Study}

This study explores whether explicit form-focused instruction effectively enhances learners' ability of obtaining the semantic interpretation marked by subjunctive and indicative in predicative conditional clauses. In the following sections, I will present the details of the experiment.

\subsection{Participants}

Three groups participated in this study: (1) native group (2) tutored group (3) untutored group. The native group consisted of five Spanish native speakers from Spain, three males and two females aged from 15 to 40 . The participants in both the tutored and the untutored groups were Chinese native speakers who started to learn English as the L2 between the age of six to nine. They began to learn Spanish as the L3 in college. All Chinese-speaking participants did not have any exposure to Spanish prior to college, and they were seniors majoring in Spanish. Their age ranged between 20 and 22 years old.

There were 14 participants in the tutored group, four males and 10 females. All participants in this group reported that they had passed the intermediate-high level English proficiency test, which is one of the requirements for graduation. They reported to have an average of 20.4 hours of informal exposure to English on weekly basis. As for their L3 Spanish, 13 of them had passed DELE exam at B1 level (intermediate), and one had passed the B2 level (intermediate-high) exam. Their average hours of informal exposure to Spanish was 8.8 hours per week. These participants were registered to the fourth-year Spanish grammar class at the time of participation. They received explicit form-focused instruction on the subjunctive mood in predictive conditional clauses during the class period. The details of the instruction will be presented in the next section.

The untutored group had 12 participants, two males and 10 females. Like the tutored group, all participants had full-filled the graduation requirement for English proficiency. The average hours of informal exposure to English is 10.3 hours/week. Regarding their Spanish proficiency, 12 had passed the B1 level DELE exam or equivalent, and one did not report the Spanish proficiency exam result. Their average informal exposure to Spanish was 3.6 hour per week. The untutored group was registered to a Hispanic history class. The participants were not taking any Spanish grammar class at the time of participation. Although both tutored and untutored groups received form-focused instruction on the structure of conditional subordinate clause in previous grammar class, no explicit explanation was provided regarding the difference between the realis and irrealis conditions. In addition, according to the instructors, the irrealis conditions marked by the pluperfect subjunctive were not covered in previous class.

\subsection{Methods}

\subsubsection{Materials}

The materials included a background questionnaire and three preference tests. The purpose of administering a background questionnaire was to gather the information on the participants' learning experience and demographic data. The Chinese-speaking learners were also asked to report their recent English and Spanish proficiency test scores and average hours of informal exposure to these languages. All participants were asked to complete the questionnaire.

\subsubsection{Preference Tests}

Three preference tests were implemented at different stages: pretest, posttest 1 , posttest 2 . In each test, there were four categories of questions: (1) possible predictive condition (e.g. Si quieres, voy al hospital contigo. [If you want, I will go to the hospital with you.]) (2) irrealis condition in present (e.g. Si fuera un pájaro, volaría en el cielo. [If I were a bird, I would fly in the sky.]) (3) irrealis in past (e.g. Si hubieras venido más temprano, no habría ocurrido el accidente. [If you had come earlier, the accident would not have happened.]) (4) Distracters (e.g. Cuando muera Pepe, su esposa se casará con otro hombre. [When Pepe dies, his wife will marry another man.]). The purpose of including the distracters was to ensure that the participants understood the instruction and were able to perform the task. Each category consisted of five questions, which resulted in 20 questions in total. The vocabulary used in the test were selected from the textbooks that all participants in the learner groups had used in previous courses. The questions were randomized.

The participants were asked to read the sentence in each 
question and choose the preferred description of the condition from the following options: (1) describe a condition that is possible to happen (2) describe a condition that is unreal in the present (3) describe a condition that was unreal in the past. They were also instructed to leave the answer blank if they did not know the answer. In addition, they had to explain their decision in whichever language they felt comfortable with. The instruction was presented in the participants' native languages to avoid misunderstanding. There was no time limit to finish the test.

\subsubsection{Procedure}

Both the tutored and the untutored groups completed the materials as part of class activities. In the first week, both groups received a packet including an informed consent form, a background questionnaire and the pretest. They completed the packet in their respective classes. The whole process took approximately an hour. After completing the materials, the untutored group continued with their Hispanic history class without receiving any instruction on the Spanish subjunctive or the subordinate clause structures. The native speakers completed the same materials on-line.

The instruction for the tutored group began in the second week. It consisted of two consecutive sessions, and each session lasted for two hours. The instruction was conducted mainly in Spanish, explanations in Chinese were given when learners encountered difficulties in comprehending the instruction. First, the instructor reviewed verb conjugation for the imperfect subjunctive and the pluperfect subjunctive. The instructor showed the structure of predictive conditional clauses in Powerpoint, using colors to draw learners' attention to the target structure. Then, the interpretation of the indicative and the subjunctive markings in conditional clauses was explained with the following examples:

(14) Si me toca la lotería, te compraré una casa. If I win the lottery, I will buy you a house.

(15) Si me toca la lotería, te voy a comprar una casa. If I win the lottery, I am going to buy you a house.

(16) Si me toca la lotería, te compro una casa. If I win the lottery, I am definitely going to buy you a house.

(17) Si me tocara la lotería, te compraría una casa. If I won the lottery, I would buy you a house.

(18) Si me hubiera tocado la lotería, te habría comprado una casa.

If I had won the lottery, I would have bought you a house.

The verbs in the principal and the subordinate clauses were marked in different colors to attract learners' attention and to make the distinction. Each sentence was presented on an individual slide, with explanation presented within context. Then the instructor showed a slide with the following sentences:

(19) Si me dan la beca, estudiaré en España. If they give me the scholarship, I will study in Spain.

(20) Si me dan la beca, voy a estudiar en España.
If they give me the scholarship, I am going to study in Spain.

(21) Si me dan la beca, estudio en España.

If they give me the scholarship, I am definitely going to study in Spain.

(22) Si me diera la beca, estudiaría en España.

If they gave me the scholarship, I would study in Spain.

(23) Si me hubiera dado la beca, habría estudiado en España. If they had given me the scholarship, I would have studied in Spain.

The students worked in pair to come up with a context for each of these sentences and to explain why they thought such context was appropriate for the sentence. During the presentation, their peers were allowed to make corrections or to ask questions. The instructor intervened the presentation whenever a clarification of concept or a correction was needed. The presentation was conducted in Spanish.

The class concluded with an exercise with 20 items that required the students to provide correct verb conjugation in each conditional clause. They completed half of the items in class and presented their answers. The instructor made necessary corrections and answered students' questions. The rest of the exercise was for homework. In addition, they received a sentence production exercise. The sentence production exercise consisted of ten situations, and the students were asked to write a sentence consisting of a conditional clause that is appropriate for the context. An example is presented in (24):

(24) De pequeña, María quería ser bailarina, pero suspadres no la dejaban. Ahora ella tiene 40 años, cuando ve los espectáculos de baile, siempre dice:

As a child, Maria wanted to be a dancer, but her parents did not let her. Now she is 40 years old, when she sees a dance presentation, she always says:

The second session continued in the following week. It began with a review on the homework. Then, the students received an article adapted from "Apple podría comprar todos los equipos de la NBA, NFL, MLS y NHL" (http://cnnespanol.cnn.com/2015/04/28/apple-podria-comprar -todos-los-equipos-de-la-nba-nfl-mls-y-nhl/). They were asked to read the article and underline all the conditional clauses. At the end of the article, students answered five open-ended comprehension questions and discussed their interpretation of each conditional clause in groups of three or four. Each group shared their work with the class. The instructor commented on students' responses and provided further explanation on the reading content or sentence structures. Finally, as a follow-up activity, students shared their opinions on the following questions:

a. ¿Quieres ser tan rico como Apple? ¿Por qué sí o por qué no?

Do you want to be as rich as Apple? Why or why not?

b. ¿Qué harías si fueras tan rico como Apple?

What would you do if you were as rich as Apple? 
c. Si Apple comprara todos los equipos mencionados, ¿cómo sería el mundo del deporte profesional?

If Apple bought all the teams mentioned, how would the professional sports world be?

d. Si los fundadores de Apple no hubiera creado la compañía, ¿qué habría ocurrido y cómo sería nuestra vida?

If the funders of Apple had not created the company, what would have happened and how would our life be?

After the lesson, the students took the first posttest immediately. The untutored and the native groups took the same test in the same week. Posttest 2 was administered to all participants two weeks after. The natives completed all tests on-line.

\section{Results}

To investigate the instructional effects on the participants' interpretation of the conditional clauses marked with different moods, the responses from each group were analyzed. For statistical purpose, the participants' responses were converted into scores. Each correct response received one point. The maximum of the total score in each category was five (i.e. one point for each correct item, and there were five items in each category). The results are presented in the following order: (1) distracters (2) pretest (3) posttest 1 (4) posttest 2 (5) Comparison between the tests. One-way ANOVA analysis was conducted to compare the three group's scores in the tests, with $a$ level at 0.05 .

\subsection{Distracters}

The purpose of including distracters in the test was to ensure that the participants understood the instructions and were able to perform the task. Before presenting the results, it is necessary to present the participants' responses to the distracters (e.g. Cuando llego a casa, siempre llamo a mi madre primero. [When I arrive home, I always call my mom first]). There was no significant difference between the native and the learner groups in all three tests (pretest: $\mathrm{F}(2,28)=.54$, $\mathrm{p}=.59$; posttest $1: \mathrm{F}(2,28)=.55, \mathrm{p}=.58$; posttest $2: \mathrm{F}(2$, $28)=.06, \mathrm{p}=.94$, ). As illustrated in Table 1, the three groups' average score in the distracter category ranged from 4.4 to 5 , which suggests that the participants got all questions correct or made error in only one question. This indicates that the participants were capable of carrying out the task and their responses in the tests were reliable.

Table 1. The participants' average scores in distracters

\begin{tabular}{|c|c|c|c|c|c|c|}
\hline & \multicolumn{2}{|c|}{ Native } & \multicolumn{2}{c|}{ Tutored } & \multicolumn{2}{c|}{ Untutored } \\
\hline & $\mathrm{M}$ & $\mathrm{SD}$ & $\mathrm{M}$ & $\mathrm{SD}$ & $\mathrm{M}$ & $\mathrm{SD}$ \\
\hline Pretest & 5 & 0 & 4.4 & 0.3 & 4.4 & 0.3 \\
\hline Posttest 1 & 4.86 & 0.13 & 4.43 & 0.57 & 4.43 & 0.26 \\
\hline Posttest 2 & 4.75 & 0.39 & 4.6 & 0.24 & 4.5 & 0.64 \\
\hline
\end{tabular}

\subsection{Pretest}

For the conditional clauses marked with the present indicative (e.g. Si hace buen tiempo, vamos a la playa. [If the weather is nice, we go to the beach]), all groups interpreted these items as realis. The natives' average score was $5(\mathrm{SD}=0)$, and the learner groups' average was close to 4 (i.e. tutored: $\mathrm{M}=4, \mathrm{SD}=1.23$; untutored: $\mathrm{M}=4.08, \mathrm{SD}=1.54$ ). Although there was a difference between the natives' and the learner groups' mean scores, such difference was not significant $(\mathrm{F}(2$, $28)=1.67, p=.2$ ). The percentage of the participants' responses in each sentence category is presented in Table 2. All natives and more than $80 \%$ of the learners interpreted the clauses marked with the present indicative as realis condition. However, there were about $10 \%$ of the participants in both learner groups that preferred the irrealis in present interpretation (i.e. tutored: $10 \%$ [7/70], untutored: $11.67 \%$ [7/60]). In addition, $10 \%(7 / 70)$ of the participants in the tutored group, and $6.66 \%(4 / 60)$ of those in the untutored group interpreted the present indicative marking as irrealis in past.

On the other hand, a significant difference was found between the three groups' responses to the clauses marked with the imperfect subjunctive (e.g. Si me tocara la lotería, viajaria por todo el mundo ahora mismo. [If I won the lottery, I would travel around the world now.]) $(\mathrm{F}(2,28)=5.14$, $p=.0125)$. The native group scored 4.6 by average $(\mathrm{SD}=.3)$, while the learner groups scored 1.79 (i.e. tutored, $\mathrm{SD}=3.87$ ) and 1.67 (i.e. untutored, $\mathrm{SD}=3.88$ ) respectively. Post-hoc Tukey HSD test indicated that the native group's average score was significantly higher than the tutored and the untutored groups (native vs. tutored: $p=.017$; native vs. untutored: $p=.015$ ), but no significant difference was found between learner groups $(p=.89)$. As presented in Table 2, the tutored group showed a stronger preference for the irrealis in past interpretation (51.43\% [36/70]) than for irrealis in present $(35.71 \%[25 / 70])$. On the other hand, the untutored group demonstrated equal preference for both interpretations (i.e. irrealis in present:40\% [24/60]; irrealis in past:38.33\% [23/60]).

Regarding the participants' responses to the conditional clauses marked with the pluperfect subjunctive (e.g. $\mathrm{Si}$ hubiérais llamado la policía, no habría escapado el ladrón [If you had called the police, the thief would not have escaped]), there was no significant difference between groups $(\mathrm{F}(2$, $28)=1.47, p=.24)$. The native group's average score was 4.8 $(\mathrm{SD}=.8)$ and the learner groups' scores were 3.57 (i.e. tutored, $\mathrm{SD}=2.73$ ) and 3.75(i.e. untutored, $\mathrm{SD}=1.65$ ). The results in Table 2 show that irrealis in past was the most preferable interpretation in all groups (i.e. native: $96 \%$ [24/25], tutored: $71.43 \%$ [50/70], untutored: $75 \%$ [45/60]).

The pretest's results indicate that the imperfect subjunctive marking causes most difficulty in interpreting the conditional clauses. Learners were able to detect the realis condition marked by the indicative and the irrealis in past interpretation marked by the pluperfect subjunctive. However, the conditional clauses marked with the imperfect subjunctive 
caused confusion. Both learner groups were able to identify the irrealis condition, but they had difficulty in determining whether such condition was related to the present or the past. In addition, no significant difference was found between the tutored and the untutored group in all sentence category. This shows that the tutored and the untutored groups' knowledge of mood marking in predictive conditional clauses did not differ from each other prior to the instruction.

\subsection{Posttest 1}

For the conditional clauses marked with the present indicative, the three groups did not significantly differ from each other $(\mathrm{F}(2,28)=.43, \mathrm{p}=.65)$, and all groups scored above 4.5 (i.e. native: $\mathrm{M}=4.8, \mathrm{SD}=.2$; tutored: $\mathrm{M}=4.64$, $\mathrm{SD}=.4$; untutored: $\mathrm{M}=4.5, \mathrm{SD}=.45$ ). As illustrated in Table 3, more than $90 \%$ of the responses preferred the realis interpretation in all groups (native: 96 [24/25]; tutored: 92.86\% [65/70]; untutored: 90\% [54/60]).

Regarding the imperfect subjunctive marking, the average score of the native group was $4.8(\mathrm{SD}=.2)$ and the tutored and untutored groups' scores were $3.07(\mathrm{SD}=2.69)$ and 2 $(\mathrm{SD}=3.82)$. A significant difference was found between groups $(\mathrm{F}(2,28)=5.07, \mathrm{p}=.01)$. Post-hoc Tukey HSD tests indicate that the difference was between the native and the untutored group $(\mathrm{p}=.01)$. No significant difference was found between the native and the tutored group $(p=.13)$ and between the tutored and untutored groups $(p=.25)$. The percentage indicated in Table 3 reveals that both the natives and the tutored learners preferred irrealis in present (i.e. native: $96 \%$ [24/25]; tutored: $61.43 \%$ [43/70]). On the other hand, the untutored group demonstrated equal preference for irrealis in present $(40 \%$ [24/60]) and irrealis in past $(41.67 \%$ [24/60]).

Let us now turn to the results for the pluperfect subjunctive marking. One item in this category was eliminated because two natives did not respond to the question. Since these participants did not leave a comment on why they skipped the question, it was unclear whether they missed out the item by accident or they were unable to provide a correct interpretation. Hence the number of native speakers was small $(n=5)$, each response had a great impact on the results. Thus, this item was eliminated from the analysis. The average scores of the three groups were close to 3 (i.e. native: $\mathrm{M}=3.8, \mathrm{SD}=.2$; tutored: $\mathrm{M}=3.36, \mathrm{SD}=.56$; untutored: $\mathrm{M}=3.08, \mathrm{SD}=1.17)$. No significant difference was found between these groups $(\mathrm{F}(2,28)=1.23, \mathrm{p}=.31)$. The percentages presented in Table 3 indicate that both native and learner groups preferred the irrealis in past interpretation for the clauses marked with the pluperfect subjunctive.

\subsection{Posttest 2}

For the conditional clauses marked with the present indicative, the native group's average score was $5(\mathrm{SD}=0)$. The tutored and untutored groups scored $4.64(\mathrm{SD}=.55)$ and $4.83(\mathrm{SD}=.15)$ respectively. The statistical results indicated that there was no difference between the three groups' average scores $(\mathrm{F}(2,28)=.85, \mathrm{p}=.44)$. The data illustrated in Table 4 shows that all natives preferred the realis interpretation. In addition, more than $90 \%$ of the learners' responses also chose the realis condition (i.e. tutored: $92.86 \%$ [65/70]; untutored: $96.66 \%$ [58/60]).

Regarding the clauses with the imperfect subjunctive, both the tutored and untutored groups had a lower average score than the native group (i.e. native: $\mathrm{M}=4.4, \mathrm{SD}=.4$; tutored: $\mathrm{M}=3.71, \mathrm{SD}=.38$; untutored: $\mathrm{M}=2.33, \mathrm{SD}=.61)$. The statistical results reveal that the difference between these three groups was significant $(\mathrm{F}(2,28)=3.49, \mathrm{p}=.04)$. However, the post-hoc Tukey HSD tests did not show any significant difference between groups (i.e. native vs. tutored: $p=.7$; native vs. untutored: $p=.07$; tutored vs. untutored: $p=.11$ ). The $p$ value of the post-hoc tests suggests that the difference between the native and the untutored groups might have contributed to the statistically significant difference revealed by the one-way ANOVA analysis. This will be further discussed in the discussion section. In addition, the percentage presented in Table 4 indicates that the majority of the natives preferred the irrealis in present interpretation for the imperfect subjunctive marking (i.e.88\% [22/25]), and so did the tutored learners (74.29\% [52/70]), but the untutored group showed preference for both irrealis in present (i.e.46.67\% [28/60]) and irrealis in past (i.e. $41.66 \%[25 / 60])$.

Table 2. Distribution of the participants' responses in pretest

\begin{tabular}{|c|c|c|c|c|c|c|c|c|c|}
\hline \multirow{2}{*}{ Group } & \multicolumn{3}{|c|}{$\begin{array}{l}\text { conditional clauses marked with the } \\
\text { present indicative }\end{array}$} & \multicolumn{3}{|c|}{$\begin{array}{l}\text { conditional clauses marked with the } \\
\text { imperfect subjunctive }\end{array}$} & \multicolumn{3}{|c|}{$\begin{array}{l}\text { conditional clauses marked with } \\
\text { the pluperfect subjunctive }\end{array}$} \\
\hline & $\begin{array}{c}\text { Native } \\
\% \\
\text { (n) }\end{array}$ & $\begin{array}{c}\text { Tutored } \\
\% \\
\text { (n) }\end{array}$ & $\begin{array}{c}\text { Untutored } \\
\% \\
\text { (n) }\end{array}$ & $\begin{array}{c}\text { Native } \\
\% \\
\text { (n) }\end{array}$ & $\begin{array}{c}\text { Tutored } \\
\% \\
\text { (n) }\end{array}$ & $\begin{array}{c}\text { Untutored } \\
\% \\
\text { (n) }\end{array}$ & $\begin{array}{c}\text { Native } \\
\% \\
\text { (n) }\end{array}$ & $\begin{array}{c}\text { Tutored } \\
\% \\
\text { (n) }\end{array}$ & $\begin{array}{c}\text { Untutored } \\
\% \\
\text { (n) }\end{array}$ \\
\hline realis & $\begin{array}{l}100 \\
(25)\end{array}$ & $\begin{array}{c}80 \\
(56)\end{array}$ & $\begin{array}{c}81.67 \\
(49)\end{array}$ & $\begin{array}{c}8 \\
(2)\end{array}$ & $\begin{array}{c}8.57 \\
(6)\end{array}$ & $\begin{array}{c}16.67 \\
(2)\end{array}$ & $\begin{array}{c}4 \\
(1)\end{array}$ & $\begin{array}{c}7.17 \\
(5)\end{array}$ & $\begin{array}{c}3.33 \\
(2)\end{array}$ \\
\hline irrealis in present & $\begin{array}{c}0 \\
(0)\end{array}$ & $\begin{array}{l}10 \\
(7)\end{array}$ & $\begin{array}{c}11.67 \\
(7)\end{array}$ & $\begin{array}{c}92 \\
(23)\end{array}$ & $\begin{array}{c}35.71 \\
(25)\end{array}$ & $\begin{array}{c}40 \\
(24)\end{array}$ & $\begin{array}{c}0 \\
(0)\end{array}$ & $\begin{array}{c}21.43 \\
(15)\end{array}$ & $\begin{array}{c}21.67 \\
(13)\end{array}$ \\
\hline irrealis in past & $\begin{array}{c}0 \\
(0)\end{array}$ & $\begin{array}{l}10 \\
(7)\end{array}$ & $\begin{array}{c}6.66 \\
(4)\end{array}$ & $\begin{array}{c}0 \\
0 \\
(0)\end{array}$ & $\begin{array}{c}51.43 \\
(36)\end{array}$ & $\begin{array}{c}38.33 \\
(23)\end{array}$ & $\begin{array}{l}96 \\
(24)\end{array}$ & $\begin{array}{c}71.43 \\
(50)\end{array}$ & $\begin{array}{c}75 \\
(45)\end{array}$ \\
\hline No response & $\begin{array}{c}0 \\
(0)\end{array}$ & $\begin{array}{c}0 \\
(0)\end{array}$ & $\begin{array}{c}0 \\
(0)\end{array}$ & $\begin{array}{c}0 \\
(0)\end{array}$ & $\begin{array}{c}4.29 \\
(3)\end{array}$ & $\begin{array}{c}5 \\
(3)\end{array}$ & $\begin{array}{c}0 \\
(0)\end{array}$ & $\begin{array}{c}0 \\
(0)\end{array}$ & $\begin{array}{c}0 \\
(0)\end{array}$ \\
\hline
\end{tabular}

Native: $\mathrm{N}=25$, Tutored: $\mathrm{N}=70$, Untutored: $\mathrm{N}=60$ 
Table 3. Distribution of the participants' responses in posttest 1

\begin{tabular}{|c|c|c|c|c|c|c|c|c|c|}
\hline \multirow{2}{*}{$\underbrace{\text { Sentence type }}_{\text {Interpretation }}$} & \multicolumn{3}{|c|}{$\begin{array}{l}\text { conditional clauses marked with the } \\
\text { present indicative }\end{array}$} & \multicolumn{3}{|c|}{$\begin{array}{l}\text { conditional clauses marked with the } \\
\text { imperfect subjunctive }\end{array}$} & \multicolumn{3}{|c|}{$\begin{array}{l}\text { conditional clauses marked with } \\
\text { the pluperfect subjunctive* }\end{array}$} \\
\hline & $\begin{array}{c}\text { Native } \\
\% \\
\text { (n) }\end{array}$ & $\begin{array}{c}\text { Tutored } \\
\% \\
\text { (n) }\end{array}$ & $\begin{array}{c}\text { Untutored } \\
\% \\
\text { (n) }\end{array}$ & $\begin{array}{c}\text { Native } \\
\% \\
\text { (n) }\end{array}$ & $\begin{array}{c}\text { Tutored } \\
\% \\
\text { (n) }\end{array}$ & $\begin{array}{c}\text { Untutored } \\
\% \\
\text { (n) }\end{array}$ & $\begin{array}{c}\text { Native } \\
\% \\
\text { (n) }\end{array}$ & $\begin{array}{c}\text { Tutored } \\
\% \\
\text { (n) }\end{array}$ & $\begin{array}{c}\text { Untutored } \\
\% \\
\text { (n) }\end{array}$ \\
\hline realis & $\begin{array}{c}96 \\
(24) \\
\end{array}$ & $\begin{array}{c}92.86 \\
(65) \\
\end{array}$ & $\begin{array}{c}90 \\
(54) \\
\end{array}$ & $\begin{array}{c}4 \\
(1) \\
\end{array}$ & $\begin{array}{c}5.71 \\
(4)\end{array}$ & $\begin{array}{c}18.33 \\
(11)\end{array}$ & $\begin{array}{c}5 \\
(1) \\
\end{array}$ & $\begin{array}{c}0 \\
(0)\end{array}$ & $\begin{array}{c}2.08 \\
(1)\end{array}$ \\
\hline irrealis in present & $\begin{array}{c}4 \\
(1)\end{array}$ & $\begin{array}{c}5.71 \\
(4)\end{array}$ & $\begin{array}{c}3.33 \\
(2)\end{array}$ & $\begin{array}{c}96 \\
(24)\end{array}$ & $\begin{array}{c}61.43 \\
(43)\end{array}$ & $\begin{array}{c}40 \\
(24)\end{array}$ & $\begin{array}{c}0 \\
0 \\
(0)\end{array}$ & $\begin{array}{l}16.07 \\
(9)\end{array}$ & $\begin{array}{c}20.84 \\
(10)\end{array}$ \\
\hline irrealis in past & $\begin{array}{c}0 \\
(0)\end{array}$ & $\begin{array}{c}1.43 \\
(1)\end{array}$ & $\begin{array}{l}6.67 \\
(4)\end{array}$ & $\begin{array}{c}0 \\
(0)\end{array}$ & $\begin{array}{c}32.86 \\
(23)\end{array}$ & $\begin{array}{l}41.67 \\
(25)\end{array}$ & $\begin{array}{c}95 \\
(19)\end{array}$ & $\begin{array}{c}83.93 \\
(47)\end{array}$ & $\begin{array}{l}77.08 \\
(37)\end{array}$ \\
\hline No response & $\begin{array}{c}0 \\
(0)\end{array}$ & $\begin{array}{c}0 \\
0 \\
(0)\end{array}$ & $\begin{array}{c}0 \\
0 \\
(0)\end{array}$ & $\begin{array}{c}0 \\
(0)\end{array}$ & $\begin{array}{c}0 \\
(0)\end{array}$ & $\begin{array}{c}0 \\
(0)\end{array}$ & $\begin{array}{c}0 \\
(0)\end{array}$ & $\begin{array}{c}0 \\
(0)\end{array}$ & $\begin{array}{c}0 \\
(0)\end{array}$ \\
\hline
\end{tabular}

Native: $\mathrm{N}=25$, Tutored: $\mathrm{N}=70$, Untutored: $\mathrm{N}=60$

*One test item was eliminated

Table 4. Distribution of the participants' responses in posttest 2

\begin{tabular}{|c|c|c|c|c|c|c|c|c|c|}
\hline Sentence type & \multicolumn{3}{|c|}{$\begin{array}{l}\text { conditional clauses marked with the } \\
\text { present indicative }\end{array}$} & \multicolumn{3}{|c|}{$\begin{array}{l}\text { conditional clauses marked with the } \\
\text { imperfect subjunctive }\end{array}$} & \multicolumn{3}{|c|}{$\begin{array}{l}\text { conditional clauses marked with } \\
\text { the pluperfect subjunctive }\end{array}$} \\
\hline $\begin{array}{l}\text { Group } \\
\text { Interpretation }\end{array}$ & $\begin{array}{l}\text { Native } \\
\% \\
\text { (n) }\end{array}$ & $\begin{array}{c}\text { Tutored } \\
\% \\
\text { (n) }\end{array}$ & $\begin{array}{c}\text { Untutored } \\
\% \\
\text { (n) }\end{array}$ & $\begin{array}{c}\text { Native } \\
\% \\
\text { (n) }\end{array}$ & $\begin{array}{c}\text { Tutored } \\
\% \\
\text { (n) }\end{array}$ & $\begin{array}{c}\text { Untutored } \\
\% \\
\text { (n) }\end{array}$ & $\begin{array}{l}\text { Native } \\
\% \\
\text { (n) }\end{array}$ & $\begin{array}{l}\text { Tutored } \\
\% \\
\text { (n) }\end{array}$ & $\begin{array}{c}\text { Untutored } \\
\% \\
\text { (n) }\end{array}$ \\
\hline realis & $\begin{array}{l}100 \\
(25)\end{array}$ & $\begin{array}{c}92.86 \\
(65)\end{array}$ & $\begin{array}{c}96.66 \\
(58)\end{array}$ & $\begin{array}{c}8 \\
(2)\end{array}$ & $\begin{array}{c}5.71 \\
(4)\end{array}$ & $\begin{array}{c}11.67 \\
(7)\end{array}$ & $\begin{array}{c}8 \\
(2)\end{array}$ & $\begin{array}{c}1.43 \\
(1)\end{array}$ & $\begin{array}{c}0 \\
(0)\end{array}$ \\
\hline irrealis in present & $\begin{array}{c}0 \\
(0)\end{array}$ & $\begin{array}{c}7.14 \\
(5)\end{array}$ & $\begin{array}{c}1.67 \\
(1)\end{array}$ & $\begin{array}{c}88 \\
(22)\end{array}$ & $\begin{array}{c}74.29 \\
(52)\end{array}$ & $\begin{array}{c}46.67 \\
(28)\end{array}$ & $\begin{array}{c}0 \\
(0)\end{array}$ & $\begin{array}{c}21.43 \\
(15)\end{array}$ & $\begin{array}{c}33.33 \\
(20)\end{array}$ \\
\hline irrealis in past & $\begin{array}{c}0 \\
(0)\end{array}$ & $\begin{array}{c}0 \\
(0)\end{array}$ & $\begin{array}{l}1.67 \\
(1)\end{array}$ & $\begin{array}{c}4 \\
(1)\end{array}$ & $\begin{array}{c}18.57 \\
(13)\end{array}$ & $\begin{array}{c}41.66 \\
(25) \\
\end{array}$ & $\begin{array}{c}92 \\
(23) \\
\end{array}$ & $\begin{array}{c}77.14 \\
(54)\end{array}$ & $\begin{array}{c}66.67 \\
(40)\end{array}$ \\
\hline No response & $\begin{array}{c}0 \\
(0)\end{array}$ & $\begin{array}{c}0 \\
(0)\end{array}$ & $\begin{array}{c}0 \\
0\end{array}$ & $\begin{array}{c}0 \\
(0)\end{array}$ & $\begin{array}{c}0 \\
(0)\end{array}$ & $\begin{array}{c}0 \\
(0)\end{array}$ & $\begin{array}{c}0 \\
0\end{array}$ & $\begin{array}{c}0 \\
(0)\end{array}$ & $\begin{array}{c}0 \\
(0)\end{array}$ \\
\hline
\end{tabular}

Native: $\mathrm{N}=25$, Tutored: $\mathrm{N}=70$, Untutored: $\mathrm{N}=60$

As for the clauses marked with the pluperfect subjunctive, the natives' mean score was $4.8(\mathrm{SD}=.2)$. Both the tutored and the untutored groups scored around 3 (i.e. tutored: $\mathrm{M}=3.86$, $\mathrm{SD}=.75$; untutored: $\mathrm{M}=3.33, \mathrm{SD}=2.79$ ). The difference between the three groups was not statistically significant $(\mathrm{F}(2,28)=2.6, \mathrm{p}=.09)$. The distribution of the participants' responses presented in Table 4 indicates that irrealis in past was the most preferable interpretation for the pluperfect subjunctive (i.e. native: $92 \%$ [23/25]; tutored: $77.14 \%$ [54/70]; untutored: $66.67 \%$ [40/60]). However, there were nearly 20 percent of the responses in the tutored groups were for irrealis in present (i.e. native: $24 \%$ [6/25]; tutored: $21.43 \%$ [13/70]). In addition, the untutored group's percentage of responses for the irrealis in present interpretation was higher than the other two groups (i.e. $33.33 \%$ [20/60]).

In sum, the results of the three tests demonstrate that instruction was more effective for the clauses marked with the imperfect subjunctive than the others. To further investigate the effectiveness of the instruction, it is necessary to compare the learners' responses between tests. The results of paired-sample t-test comparing the learner groups' responses between tests will be presented in the next section.

\subsection{Comparison between Tests}

To further examine the effects of form-focused instruction, two-tailed paired-samples t-test was conducted to compare the learner groups' responses between tests. The $\square$ level is at 0.05 . For the conditional clauses with realis interpretation, the tutored group's average score in the pretest was $4(\mathrm{SD}=1.23)$, and its average score in posttest 1 was $4.64(\mathrm{SD}=.4)$. The untutored group scored $4.08(\mathrm{SD}=1.54)$ and $4.5(\mathrm{SD}=.45)$ in the pretest and posttest 1 respectively. As for the second posttest, the tutored group's average was $4.64(\mathrm{SD}=.55)$, and the untutored group's was $4.83(\mathrm{SD}=.15)$. The statistical analysis reveals no significant difference in both groups' average scores between the pretest and posttest 1(tutored: $\mathrm{t}(13)=-1.66, \mathrm{p}=.12$; untutored: $\mathrm{t}(11)=-1.82, \mathrm{p}=.09)$, and between the two posttests (tutored: $\mathrm{t}(13)=0, \mathrm{p}=1$; untutored: $\mathrm{t}(11)=-1.48, \mathrm{p}=.17)$.

On the other hand, the learners' responses to the clauses marked with the imperfect subjunctive changed over the tests. The tutored group scored $1.78(\mathrm{SD}=3.87)$ in the pretest, but the average score increased to $3.07(\mathrm{SD}=2.69)$ in the first posttest. However, the statistical result indicated that such difference was not significant $(\mathrm{t}(13)=-1.59, \mathrm{p}=.14)$. The tutored groups' average score in the second posttest was 3.71( $\mathrm{SD}=2.07)$, which did not significantly differ from the average in the first posttest $(\mathrm{t}(13)=-1.19, \mathrm{p}=.26)$. Regarding the untutored group, the average scores were $1.67(\mathrm{SD}=3.88)$ in the pretest, $2(\mathrm{SD}=3.82)$ in posttest 1 , and $2.33(\mathrm{SD}=4.42)$ in posttest 2 . No statistically significant difference was found between tests (pretest vs. posttest 1 : $\mathrm{t}(11)=-1, \mathrm{p}=.34$; posttest 1 vs. posttest 2 : $t(11)=-.89, p=.39)$. 
As for the clauses with the pluperfect subjunctive marking, the tutored group's average slightly decreased from 3.57 $(\mathrm{SD}=2.73)$ in the pretest to $3.36(\mathrm{SD}=.55)$ in posttest 1 , then increased to $3.86(\mathrm{SD}=.75)$ in posttest 2 . The difference between tests was not statistically significant (pretest vs. posttest $1: \mathrm{t}(13)=.54, \mathrm{p}=.59$; posttest 1 vs. posttest 2 : $\mathrm{t}(13)=$ $-1.61, \mathrm{p}=.13)$. The untutored group's average score in this category changed in the similar pattern as the tutored group. The untutored group's score in posttest 1 was significantly lower than the pretest $(\mathrm{t}(11)=2.97, \mathrm{p}=.01)$. Its average score in the pretest was $3.75(\mathrm{SD}=1.66)$, and it was $3.08(\mathrm{SD}=1.17)$ in posttest 1 . The untutored group's average score in posttest 2 was 3.33( $\mathrm{SD}=2.79)$, which did not significantly differ from posttest $1(\mathrm{t}(11)=-.58, \mathrm{p}=.57)$.

The analysis of the learners' responses in the tests reveals that the both tutored and untutored groups' responses were most consistent in the conditional clauses marked with the present indicative. On the other hand, although there was no statistically significant difference between the tutored group's responses to the clauses with the imperfect subjunctive marking, the tutored learners' scores in the first posttest increased. Finally, the participants in both groups responded to the clauses marked with the pluperfect subjunctive marking in similar pattern.

\section{Discussion}

\subsection{The Instructional Effects}

This study aimed to investigate whether form-focused instruction facilitates Chinese-speaking Spanish learners to obtain the appropriate interpretation entailed by the subjunctive mood in Spanish predictive conditional clauses. The results reveal that the instruction is most effective in enhancing learners' knowledge of the irrealis in present interpretation entailed by the imperfect subjunctive. On the other hand, the instructional effect is less prominent for the indicative and the pluperfect subjunctive markings.

For the conditional clauses marked with the present indicative, the tutored and untutored groups scored above 4 in the pretest, and their scores were above 4.5 in both posttests. As shown in Tables 2-4, more than $80 \%$ of the participants' responses chose the realis interpretation. The percentage of responses for the realis interpretation was above $90 \%$ in both posttests. Furthermore, the two-tailed paired-samples t-test analysis did not reveal significant difference in the learners' responses between tests. This indicates that the instruction was not effective for learners to recognize the realis interpretation marked by the indicative. Learners are familiar with the realis condition because the conditional clauses marked with the indicative were introduced at early stage. The indicative mood serves as default for marking the conditional clauses. More than $80 \%$ of the participants in the learner groups commented that they recognized the indicative morphology and they knew that it expresses a real condition.
Regarding the clauses marked with subjunctive, the instruction was more effective for the imperfective subjunctive than for the pluperfect subjunctive marking. Although the results of paired-samples t-test did not reveal significant difference in the tutored group's responses between the pretest and posttests, the tutored group's average score increased from $1.78(\mathrm{SD}=3.87)$ in the pretest to $3.07(\mathrm{SD}=2.69)$ in posttest 1 and to $3.71(\mathrm{SD}=2.07)$ in posttest 2. Moreover, in pretest, the percentage of the participants' responses for irrealis in present was $35.71 \%(25 / 70)$. It increased to $61.43 \%$ (43/70) in posttest 1 and to $74.29 \%(52 / 70)$ in posttest 2 . This suggests that the statistical insignificance revealed by the paired-samples t-test was due to the small number of participants ( $n=14)$. In addition, the standard deviation in the tutored group was greater than two in all tests, this indicates a great variation of the participants' responses, which might also contribute to the insignificant results.

On the contrary, the untutored learners did not demonstrate significant change in their interpretation for the clauses marked with the imperfect subjunctive. Their mean scores ranged between $1.67(\mathrm{SD}=3.88)$ to $2.33(\mathrm{SD}=4.42)$ in the tests. In addition, the percentage of the responses for irrealis in present and irrealis in past was around $40 \%$ in this category. This shows that they recognized the subjunctive morphology and they were able to relate it to unreal condition. What they were confused about was the tense. In other words, the untutored learners were aware that the imperfect subjunctive presents an unreal condition, but they were uncertain about whether such condition is relevant to the present or to the past.

On the other hand, the results of one-way ANOVA analysis revealed that both learner groups' average scores in the clauses marked with the imperfect subjunctive were significantly lower than the native group in the pretest. However, in posttest 1, the tutored learners' mean score did not significantly differ from the natives', but the untutored group's score was significantly lower than the native group's. As for posttest 2, although the one-way ANOVA indicated a significant difference between groups $(\mathrm{F}(2,28)=3.49, \mathrm{p}=.04)$, the post-hoc Tukey HSD test did not reveal which pair of groups contributed to such difference (i.e. native vs. tutored: $\mathrm{p}=.7$; native vs. untutored: $\mathrm{p}=.07$; tutored vs. untutored: $\mathrm{p}=.11)$. The $\mathrm{p}$ value of the comparison between the native and the untutored groups' mean scores was close to .05 , and the mean difference between these two groups was the greatest (i.e. 2.07). This suggests that the difference between the native and the untutored groups might have contributed to the significant difference indicated by the one-way ANOVA analysis. The results revealed by the post-hoc Tukey HSD test might be due to the small token in both groups (native: $n=5$, untutored: $n=12$ ).

Regarding the clauses marked with the pluperfect subjunctive, both the tutored and the untutored groups' average scores ranged between 3 and 4 . The paired-samples t-test analysis did not real any significant difference between tests in the tutored group. However, the untutored group's 
average score in posttest 1 was significantly lower than the pretest. A close look at the participants' responses, two individuals scored 1 point in posttest 1 , which contributed to the group's lower average score. This explains the significant difference found between the untutored groups' mean scores between the pretest and posttest 1 .

In all three tests, more than $70 \%$ of the responses from the tutored and the untutored groups chose irrealis in past for the pluperfect subjunctive marking. This shows that the learners in both groups were able to recognize the interpretation entailed by the pluperfect subjunctive even prior to the instruction. The morphological saliency of the pluperfect subjunctive facilitates the learners' interpretation of the irrealis in past condition. Nearly $60 \%$ of the participants in both learner groups stated that they chose irrealis in past because they recognized the irregular conjugation of "haber" and they knew that this conjugation is related to the past tense.

According to Collentine[1,3], learners' attention is more likely to be attracted by irregular forms. In his study with intermediate-level Spanish L2 learners, Collentine[1] reported that learners spent more time in processing the irregular present subjunctive verbs such as "sea" (ser [to be]), "sepa" (saber [to know]) than the regular verbs. In the present study, the pluperfect subjunctive verbs are composed by the imperfect subjunctive of the irregular auxiliary "haber" and past participle. The learners' comments indicate that the irregular verb paradigm of "haber" attracted their attention to the mood marking and helped them obtain the correct interpretation.

By contrast, the saliency of verb conjugation also caused confusion to some learners. There were 20 to 30 percent of participants in both tutored and untutored group that chose irrealis in present for the pluperfect subjunctive marking. Among those who commented their judgement, nearly 50\% of them stated that they thought the sentences expressed an unreal condition in present because the verb " hubiera" were conjugated in the imperfect subjunctive form. This suggests that the learners who chose the irrealis in present interpretation for the pluperfect subjunctive marking were unfamiliar with the plusperfect subjunctive morphology. Moreover, their interpretation was misguided by the irregular verb conjugation.

On the other hand, both learner groups' mean scores for the pluperfect subjunctive marking were lower than the natives'. The native group's average scores in the tests were close to five (i.e. pretest: 4.8; posttest 1: 3.8; posttest 2: 4.8). Moreover, the percentage of natives choosing the irrealis in past interpretation was above $90 \%$. This shows that even though the learners were aware of the irrealis in past interpretation entailed by the pluperfect subjunctive, their judgement had not reached native-like level.

From the developmental perspective, the learners' syntactic knowledge might have contributed to the effectiveness of the form-focused instruction. Collentine [2,3] claims that syntax is an essential foundation for the acquisition of the subjunctive mood. Lacking of syntactic foundation leaves learners with limited energy to notice the subjunctive morphology and semantics. Collentine et. al [27] found that learners who received explicit instruction on the syntactic structure of subordinate adjectival clauses did not differ from those who were instructed only on subjunctive marking in both recognition and production tasks. Hence, instruction was not effective to their participants because they were still at the pre-syntax stage of language development.

Unlike Collentine et. al's[27] participants, the learners in the present study had acquired the syntactic structure of the predicative conditional clause. The structure was first introduced only with indicative marking in the first year grammar course. In addition, the comments from the learner groups indicated that more than $90 \%$ of them were able to identify the conditional clauses, which demonstrates that they had already acquired the syntactic structure. This allowed the tutored group to devote their attention to the subjunctive morphology and its semantic entailment. This shows that syntactic knowledge of the target structure is crucial to maximize the effectiveness of explicit instruction on the subjunctive mood. The form-focused instruction is effective in facilitating the learners to distinguish the imperfect subjunctive from the pluperfect subjunctive. The tutored learners were more sensitive to the tense marked by the imperfect subjunctive morphology in the conditional clauses. In addition, in the pretest, more than half of the participants in both learner groups stated they interpreted the sentences by guessing. They stated that they knew the verbs were marked by the subjunctive, but they were not sure what the imperfective subjunctive morphology expresses. In the posttests, nearly $60 \%$ of the participants in the tutored group commented that their judgement was made based on the imperfective subjunctive morphology, while the untutored learners' responses remained the same. This reveals that the obstacle that Chinese-speaking Spanish L3 learners encounter in acquiring the semantic interpretation entailed by mood morphology in conditional clauses is not caused by the distinction between the indicative and the subjunctive moods. The uncertainty of the function of the imperfect subjunctive marking is the main factor that causes difficulty to the acquisition process.

\subsection{Transfer Effects}

Previous studies indicate that L1 transfer influences the acquisition of the L2 subjunctive (e.g. Bruhn de Garavito[14]; Borgonovo and Prévost[17]; Velasco-Zárate, [18]). However, the results of the present study reveal little evidence of language transfer. About one-fifth of the participants in the learner groups claimed that they used the L1 Chinese translation to obtain the realis interpretation marked by the indicative. For the clauses marked with subjunctive, less than five cases reported using the L1 or L2 knowledge to obtain the interpretation. Such results might be related to two factors: the typological distance and the development of the learners' syntactic knowledge.

Multilingual learners tend to transfer from the language 
that shares most typological similarities with the target language. (De Angelis[36]) The structures of predicative conditional clause are similar in the three language involved. They all indicate the condition with a subordinate connector (i.e. ruguo in Chinese, if in English, and si in Spanish). Nevertheless, their ways of marking the reality levels vary. The Chinese-speaking learners in the present study did not rely on L1 or L2 transfer might be related to their awareness of the morphological differences among these languages. Some learners interpret the clauses marked with indicative based on their translation in Chinese, but such method was not used to interpret those marked with subjunctive. If the learners' interpretation depends on their L1, they would do so for the clauses marked with subjunctive as well. The fact that they did not depend on their L1 Chinese to interpret those clauses suggests that the learners were conscious that their L1 and L2 did not facilitate the interpretation marked by the Spanish subjunctive.

\section{Conclusions}

This study aimed to investigate whether explicit form-focused instruction facilitates the acquisition of the subjunctive mood in the predictive conditional clauses in Spanish. The results reveal positive instructional effects on the acquisition of irrealis in present condition marked by the imperfect subjunctive. Form-focused instruction is beneficial by raising the Chinese-speaking Spanish L3 learners' awareness of the distinction between the irrealis in present and the irrealis in past marked by the subjunctive. Moreover, the instructional effects are retainable.

However, the findings of the present study are limited with several shortcomings. First of all, the number of participants in each group was limited. Implementing this study with a larger group of participants will enhance the validity of the findings. In addition, there was only one instructional method examined. Research exploring instructions with different approaches (e.g. output-centered, communicative, contrastive...etc.) will reveal which method is more effective.

Furthermore, there was only one type of instrument employed. Instruments assessing learners' knowledge from different perspectives (e.g. production, processing, and judgement) will enrich our knowledge of the development of the subjunctive in the interlanguage. The present study only examined the acquisition of the subjunctive mood in predicative conditional clauses. Exploring the Chinese-speaking Spanish learners' knowledge of the subjunctive in other syntactic structures will bring new insights to how L3 subjunctive is acquired and the development of Chinese-speaking learners' linguistic knowledge.

\section{REFERENCES}

[1] Collentine, J. The development of complex syntax and mood selection ability by intermediate level learners of Spanish, Hispania, Vol. 78, 122-135, 1995.

[2] Collentine, J. The relationship between syntactic and morphological abilities in FL learners of Spanish. In R. Leow, and C. Sanz (eds.), Spanish applied linguistics at the turn of the millennium, 20-35, Sommerville, MA: Cascadilla Press, 2000.

[3] Collentine, J. The development of subjunctive and complex-syntactic abilities among FL Spanish learners. In B. Lafford and R. Salaberry (eds.), Studies in Spanish second language acquisition: the state of the science, 74-97, Washington, DC: Georgetown University Press, 2003.

[4] Collentine, J. The acquisition and teaching of the Spanish subjunctive: an update on current findings, Hispania, Vol. 93, No.1, 39-5, 2010.

[5] Farley, A. Authentic processing instruction and the Spanish subjunctive, Hispania, Vol. 84, 289-299, 2001.

[6] Farley, A. Processing instruction, communicative value and ecological validity: a response to Collentine, Hispania, Vol. 85, No. 4, 889-895, 2002.

[7] Farley, A. Processing instruction and the Spanish subjunctive: is explicit information needed? In Van Patten, B. (ed.), Processing instruction: theory, research and commentary, 227-239, London: Lawrence Erlbaum, 2004.

[8] Gudmestad, A. L2 variation and the Spanish subjunctive: linguistic features predicting mood selection. In C. A. Klee and T. L. Face (eds.), Selected proceedings of the 7 th conference of the acquisition of Spanish and Portuguese as first and second languages, 170-184, Somverville, MA: Cascadilla Proceedings Project, 2006.

[9] Fernández, C. Reexamining the role of explicit information in processing instruction, Studies in second language acquisition, Vol. 30, 277-305, 2008.

[10] Sockwell, R., Bowen, J., and Martin, J. The grammatical structures of English and Spanish, Chicago: University of Chicago Press, 1965.

[11] Collentine, J. Processing instruction and the subjunctive, Hispania, Vol. 81, 576-587, 1998.

[12] Ellis, R. Second language in context, Englewood, Cliffs: Prentice, 1987.

[13] Bardovi-Harlig, K. and Bofman, T. Attainment of syntactic and morphological accuracy by advanced language learners, Studies in second language acquisition, Vol. 11, 17-34, 1989.

[14] Bruhn de Garavito, J. Verb complementation, coreference and tense in the acquisition of Spanish as a second language, In A. T. Pérez-Leroux and W. Glass (eds.), Contemporary perspectives in the acquisition of Spanish, 167-180, Sommerville, MA: Cascadilla Press, 1997.

[15] Givón, T. On understanding grammar, New York: Academic Press, 1979.

[16] Givón, T. Syntax: a functional-typological introduction: volume 2, Philadelphia: John Benjamins, 1990.

[17] Borgonovo, C. and Prévost, P. Knowledge of polarity 
subjunctive in L2 Spanish, In B. Beachley, A. Brown, and F. Conlin (eds.), Proceedings of the 27th Boston University conference on language development, 150-161. Sommerville, MA: Cascadilla Press, 2003.

[18] Velasco-Zárate, K. Mood-determined specificity in L2 Spanish: evidence from L1 Japanese and English speakers, In M. G. O'Brien, C. Shea, and J. Archibald (eds.), Proceedings of the 8th generative approaches to second language acquisition conference (GASLA 2006),140-147, Somerville, MA: Cascadilla Proceedings Project, 2006.

[19] Krashen, S. Principles and practice in second language acquisition, Oxford: Pergamon, 1982.

[20] Terrell, T., Baycroft, B., and Perrone, C. The subjunctive in Spanish interlanguage: accuracy and comprehensibility. In B. Van Patten, T. R. Dvorak, and J. F. Lee (eds.), Foreign language learning: a research perspective, 19-32, Cambridge: Cambridge University Press, 1987.

[21] Stokes, J. Some factors in the acquisition of the present subjunctive in Spanish, Hispania, Vol. 71, 705-710, 1988.

[22] Stokes, J. and Krashen, S. Some factors in the acquisition of the present subjunctive in Spanish: a re-analysis, Hispania, Vol. 73, 805-806, 1990.

[23] Lee, J. F. Comprehending the Spanish subjunctive: an information processing perspective, Modern language journal, Vol. 71, 50-57, 1987.

[24] Lee, J. F. and Rodríguez, R. The effects of lexemic and morphosyntactic modifications on $\mathrm{L} 2$ reading comprehension and input processing, In W. Glass and A. Pérez-Leroux(eds.), Contemporary perspectives on the acquisition of Spanish, 135-157, Somerville, MA: Cascadilla Press, 1997.

[25] Robinson, P. Learning simple and complex second language rules under implicit, incidental, rule-search, and instructed conditions, Studies in second language acquisition, Vol.18, No.1, 27-67, 1996.

[26] Robinson, P. Generalizability and automaticity of second language learning under implicit, incidental, enhanced, and instructed conditions, Studies in second language acquisition, Vol.19, No.2, 223-247, 1997.

[27] Collentine, J., Collentine, K., Clark, V., and Friginal, E. Subjunctive instruction enhanced with syntactic instruction, In S. Montrul, and F. Ordóñez (eds.), Proceedings of the 4th Hispanic linguistics symposium, 32-45, Sommerville, MA: Cascadilla Press, 2002.

[28] García, R. L. Gramática cognitiva e instrucción de procesamiento para la enseñanza de la selección modal: un estudio con aprendientes alemanes de español como lengua extranjera, Ph.D. dissertation, Universidad Nebrija, 2009.

[29] Long, M. and Robinson, P. Focus on form: theory, research, and practice, In C. Doughty and J. Williams (eds.), Focus on form in classroom second language acquisition, 15-41, Cambridge, UK: Cambridge University Press, 1998.

[30] Doughty, C. and Williams, J. Pedagogical choices in focus on form, In C. Doughty and J. Williams (eds.), Focus on form in classroom second language acquisition, 197-261, Cambridge, UK: Cambridge University Press, 1998.

[31] Sheen, R. Focus on form---a myth in the making?, ELT journal, Vol. 57, No.3, 225-233, 2003.

[32] Burgess, J. and Etherington, S. Focus on grammatical form: explicit or implicit?, System, Vol. 30, 433-458, 2002.

[33] Palmer, F. R. Mood and modality, Cambridge, UK: Cambridge University Press, 2001.

[34] Henk, H. The syntax, semantics and pragmatics of Spanish mood, Philadelphia, USA: John Benjamins Publishing Company, 2002.

[35] Solano-Araya, J. M. Modality in Spanish: an account of mood. USA: University Microfilms, 1987.

[36] De Angelis, G. Third or additional language acquisition, Clevedon, UK: Multilingual Matters, 2007 